
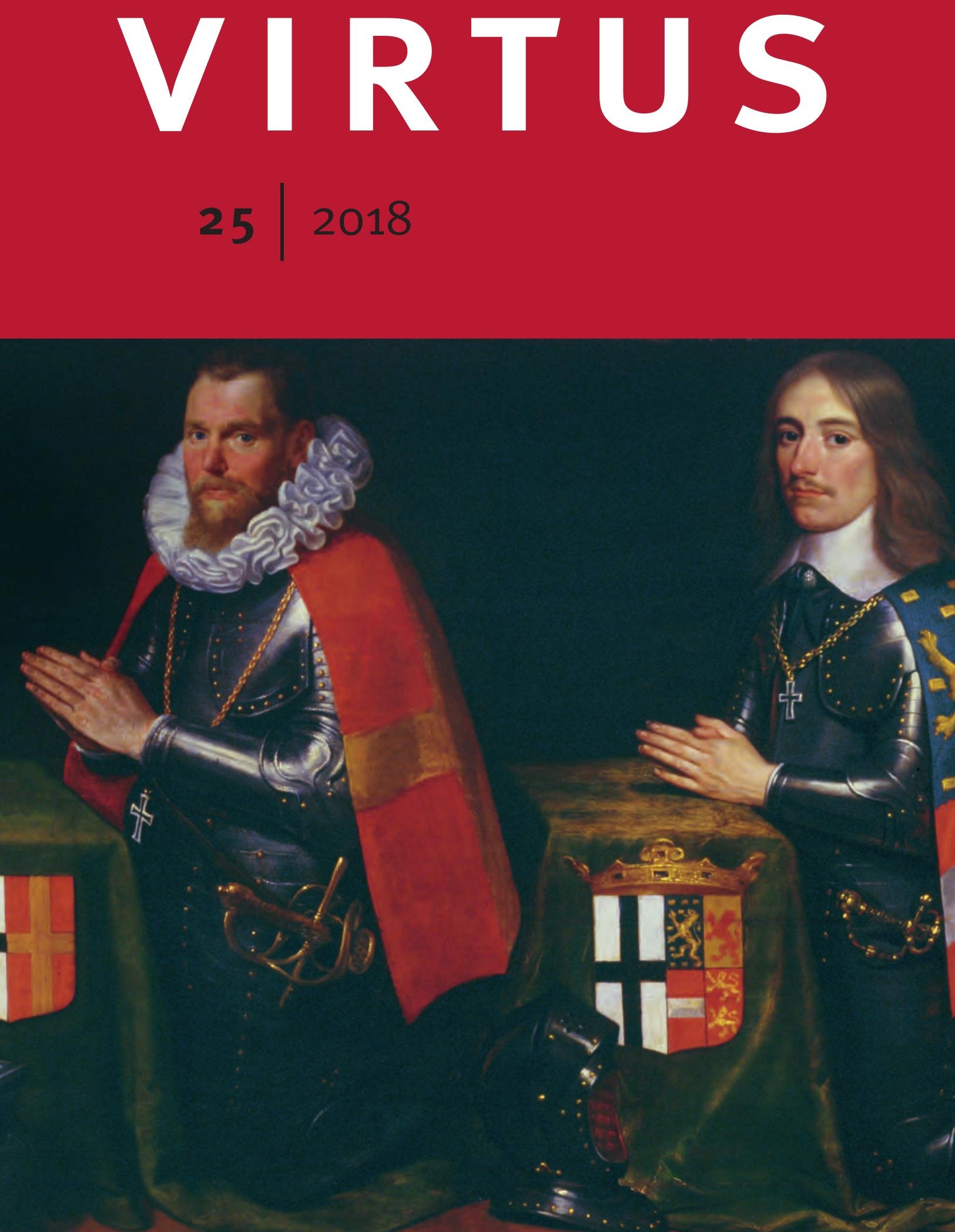


\section{Olivier Mertens}

\section{Craignez honte}

\section{The Bentinck coats of arms and their use as an expression of the cross-border character of the family}

The Bentinck family can be considered the paragon of a cross-border aristocratic family, with branches belonging to the nobility of the Holy Roman Empire (until 1806), the Dutch nobility, the English peerage and the nobility (since 1845 high nobility or Hohe Adel) of Germany, until its abolition in 1919. The origins of the Bentinck family can be found on the Veluwe, a forest rich region of the former Duchy of Guelders (Gelre), nowadays part of the Dutch province of Gelderland. The (provable) genealogy commences with Johan Bentinck, 'knape' (squire), who is mentioned in the sources between 1343 and $1386 .^{1}$ In this article, I examine whether this multinational character was apparent in the way members of the Bentinck family - with a focus on the Aldenburg Bentinck (Von Bentinck und Waldeck-Limpurg) branch ${ }^{2}$ - displayed their coats of arms and how their dynastic rise was heraldically manifested.

1 A certain Wennemarus Bentinck was already mentioned in 1304. See, for the older generations of the Bentinck family amongst others: J. de Groot, 'Bijdragen tot de oudste generaties van het geslacht Bentinck', De Nederlandsche Leeuw, LV (1937) 99-106.

2 It would take too far to consider and discuss the various coats of arms of members of the ducal branch in the United Kingdom (extinct in male lineage in 1990), descending of Henry Bentinck (16821726), second Earl of Portland (succeeding his father in 1709), elevated in the peerage as Marquess of Titchfield and Duke of Portland in 1716. 


\section{Johan Bentinck}

'knape' (squire) mentioned between 1343 and 1386

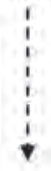

Berent Bentinck (1597-1668)

lord of Diepenheim

Eusebius Borchart

Bentinck (1643-1710)

lord of Schoonheten.

BARONIAL BRANCH

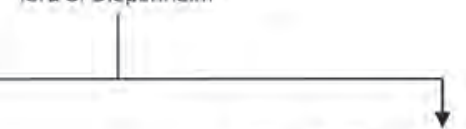

Hans Willem Bentinck (1649-1709)

1st Earl of Portland

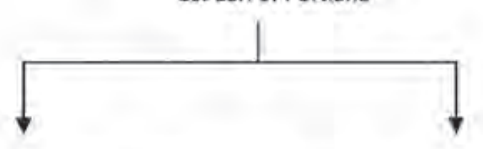

Henry Bentinck (1682-1726)

2nd Ëarl of Portland, Marquess of

Titchfield and 1st Duke of Portiand

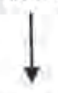

DUCAL BRANCH

Dukes of Portland
Willem Bentinck (1704-1774)

lord of Rhoon and Pendrecht and Terrington,

Count of the Holy Roman Empire

COUNTAL BRANCH

(Van/Von) Aldenburg Bentinck

Concise genealogy of the Bentinck family and its branches

\section{Heraldry}

The heraldic achievement, better known as coat of arms or armorial bearing, can be considered a quintessential European phenomenon. Coats of arms have been used by families from Norway to Portugal, from Ireland to Russia. The medieval origins of heraldry are still reminiscent in the appearance of most coats of arms. ${ }^{3}$

As in many fields and professions, heraldists have their own jargon. To a heraldist, for instance, left is called 'sinister' and right is 'dexter'. To make it more complicated: right is left and vice versa, describing the shield from the perspective of the

3 A.C. Fox-Davies, A coat of arms consists basically of a shield ('escutcheon'), a helmet with mantling, a wreath ('torse') and a crest. 
(imagined) bearer. A specific terminology for the colours ('tinctures') is used: 'purpure' (purple), 'sable' (black), 'vert' (green), 'azure' (blue) and 'gules' (red). The importance and influence of the French-speaking nobility, settled in England after the Norman Conquest in 1066 and during the reign of the house of Plantagenet, is clear; many heraldic terms are derived from the French. Gold is 'or', silver is 'argent', an eagle can be 'issuant' (rising up) and a lion can be 'regardant' (looking behind) or 'passant' (walking). However, the German language proves itself very distinct, in heraldry as well. Therefore, I have been tempted to use certain specific German heraldic terms.

\section{The Bentinck coat of arms}

The Stammwappen of the Bentinck family, the original coat of arms, can be described as: azure, a cross moline argent. As a crest, the Bentincks adopted two arms counter embowed, in red garment and gloved or, each holding an ostrich feather argent, emerging from a coronet. A cross moline is one of the many heraldic varieties of the cross and derives its name from its shape, resembling a millrind (the iron clamp) of a millstone ('moline' is the Old French word for mill). ${ }^{4}$ The figure of a cross moline is typical - although certainly not unique - for the Veluwe: various noble families from the region bore a cross moline in their arms, often in different tinctures or with different crests. Supporters were later added to these bearings of the Bentick coat of arms. By Sovereign Decree of 28 August 1814 (no. 14) five members of the baronial branches of the Bentinck family were admitted in the 'Ridderschap' (Knighthood) of the province of Overijssel..$^{5}$ The corresponding registered coat of arms (as described ut supra) is supported by two double-queued lions rampant or, langued gules.

The two arms in the Bentinck crest emerge from a coronet. In the coats of arms corresponding with the Sovereign Decree of 1814 and the Royal Decrees of 1920 and 1924the crest coronet is adorned with five leaves. This type of coronet (a helmkroon in Dutch) should not be confused with a coronet indicating a noble rank (in Dutch rangkroon). However, in British heraldry, the crest coronet is usually described as a coronet of rank and not surprisingly: 'the heraldic use of coronets of rank (...) seems

The Dutch equivalent 'ankerkruis', literally 'anchor cross', refers to the cross's resemblance with an anchor.

5 These members were: Volkier Rudolph Bentinck (1738-1820); Berend Hendrik Bentinck (1753-1830); Adolf Carel Bentinck (1764-1837); Jan Hendrik Coninck Bentinck (1787-1839); Rudolph Floris Carel Bentinck (1785-1857). In the Sovereign Warrant Decree dated 12 October 1814 (no. 39), Carel baron Bentinck (1751-1825) was admitted into the Knighthood ('Ridderschap') of Overijssel. By Royal Decree of 10 June 1819 (no. 35), king William I of the Netherlands granted all legitimate members of the Bentinck family - with an exception of the comital branch - the right to (continue to) bear their baronial title, with confirmation of the coat of arms as described in 1814. See: Nederland's adelsboek, LXXIX (1988) 357. 
Stammwappen or original coat of arms of the Bentinck family (Gritzner, ed., J. Siebmacher's grosses und allgemeines Wappenbuch, X, Tafel 2)

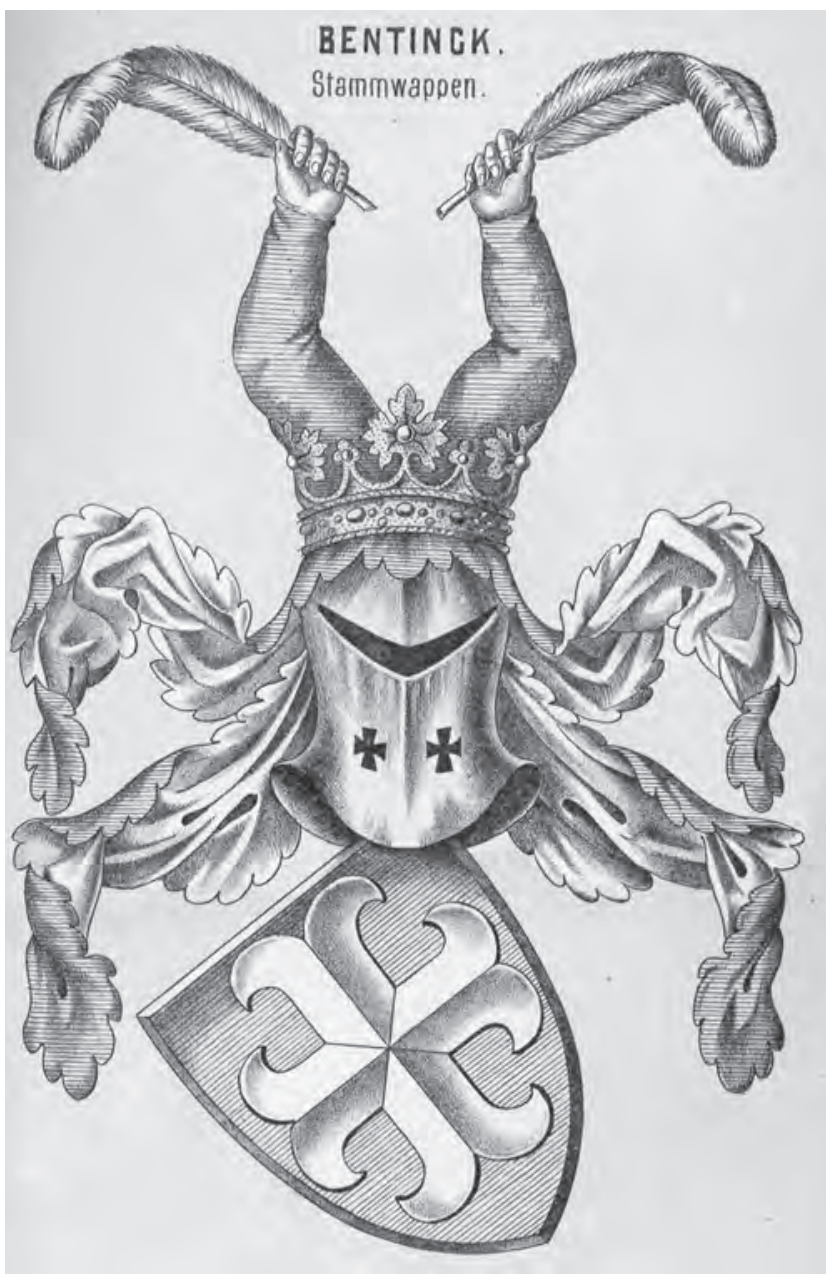

elsewhere than in Great Britain to be governed by no such strict regulations as are laid down and conformed to in this country [Great Britain]', as Arthur Fox-Davies pointed out. 'Coronets of rank are used very indiscriminately on the Continent, particularly in France and the Low Countries. Their use by no means implies the same as with us, and frequently indicates little if anything beyond mere "noble" birth.' ${ }^{6}$ In 1741, a description of the Bentinck crest read as follows: 'Out of a Marquis's Coronet, proper, two Arms counter, embow'd and vested, Gules, glov'd, Or, and holding each an 
Ostrich Feather, Argent'? The coronet of a marquess (marquis) shows three strawberry leaves (fleurons) ${ }^{8}$ and two pearls.

In case of the ducal branch of the Bentinck family (created Duke of Portland in 1716, extinct in male lineage upon the death of the ninth Duke of Portland in 1990), the crest coronet from which the arms emerge is defined as a ducal coronet, showing five strawberry leaves. According to Rietstap, the ducal coronet is the most usual crest coronet in English coats of arms. ${ }^{9}$ In my opinion, the crest coronet displayed by the Bentinck family members should not be associated with a specific noble title or rank: this coronet (indeed with five fleurons, already appearing on medieval Bentinck seals) was never intended to be a ducal crown: it had a decorative function and, as Fox-Davies remarked, originally indicated 'mere "noble" birth'. Sometimes, the coronet is even depicted on a wreath, which might be considered incorrect: a crest coronet is after all a replacement of the wreath.

\section{The coats of arms of the Aldenburg Bentinck branch}

By Decree of emperor Charles VI dated Vienna, 29 December 1732, Willem Bentinck (1704-1774), lord of Rhoon and Pendrecht and Terrington, second son of Hans Willem Bentinck, first Earl of Portland, was created Reichsgraf or Count of the Holy Empire. Six months later, the marriage between count Bentinck and Charlotte Sophie Reichsgräfin von Aldenburg (1715-1800) was celebrated. Already in 1739, the marriage ended in a legal separation.

Charlotte Sophie was heiress of the Herrschaften or lordships Varel and Kniphausen in the Duchy of Oldenburg and of Doorwerth in the Duchy of Guelders. After the death of her father, Reichsgraf Anton II von Aldenburg in 1738, these possessions came into the hands of the Bentinck family. Until 1854, the miniature state of Varel and Kniphausen would be ruled by the Bentincks. This addition to the family property led to a further modification of the bearings used by the couple's offspring.

\section{The (Aldenburg) Bentinck coat of arms (1814)}

Christiaan Frederik Anton Willem Carel (called Antoine) Bentinck (1734-1768), eldest son and heir to Rhoon and Pendrecht and Varel and Kniphausen, bore the full coat of arms of Bentinck quartered with Aldenburg, as can be seen on his impressive and elegant funerary hatchment from 1768 preserved in the church of Rhoon.

The Bentinck arms marshalled with those of Aldenburg by quartering were officially registered in the armorials of the nobility at the High Council of the Nobility

7 A. Collins, The Peerage of England. Containing a genealogical and historical account off all the Peers of England. Now existing, either by tenure, summons or creation (9 vols; London, 1709-1812), I, 436.

8 Trilobed leaves, in British heraldry referred to as 'strawberry leaves'.

9 J.B. Rietstap, Handboek der wapenkunde (Amsterdam, 1875) 291. 
Funerary hatchment of

Christiaan Frederik Anton

Willem Carel Bentinck in the

Dutch reformed church of

Rhoon (photo by G.J.

Dukker, 1980; coll.

Rijksdienst voor het

Cultureel Erfgoed, no. 210.661)

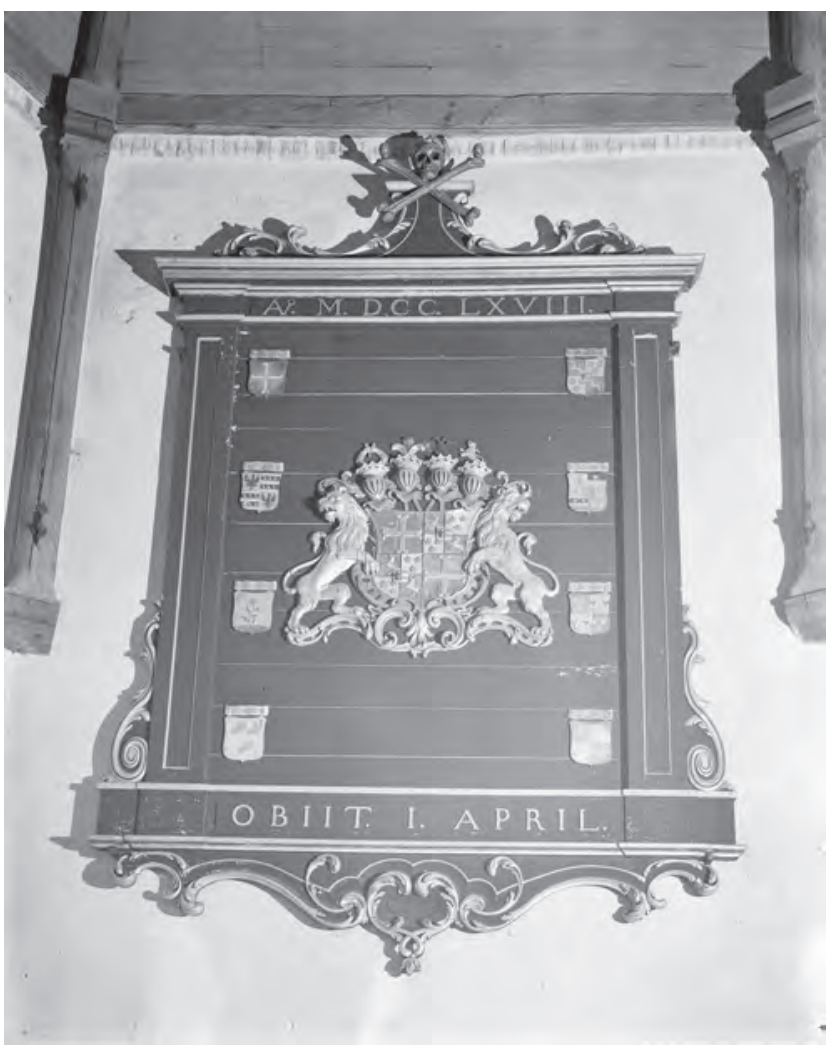

in The Hague when by Sovereign Decree of Willem I, Sovereign Prince of the Netherlands (who would become King in 1815), dated Brussels, 28 August 1814, Willem Gustaaf Frederik Bentinck van Rhoon (1762-1835) was admitted to the Chivalry of the province of Holland with homologation (recognition) of his title of graaf (count). The coat of arms depicted can be described as follows (translated in English, OM):

Quarterly. First and fourth grand quarters: azure, a cross moline argent, with a crescent or in the dexter chiefpoint. Second and third grand quarters, quarterly: first and fourth, azure, a horse rampant argent, a ribbon gules wreathed in the manes; second and third, argent, three roses gules, seeded or; over all an inescutcheon, per pale: dexter or, a double eagle sable, langued and armed gules, sinister or, two fesses gules. Four helmets, four coronets with three fleurons and two pearls. Mantling: gules, azure and gules, lined with silver. First crest: two arms counter-embossed vested gules, gloved or, each holding an ostrich feather argent; second crest: three ostrich feathers, one feather azure between two feathers or; third crest: a double eagle sable, armed and langued gules; fourth crest: a double-queued demi-lion rampant issuant or, langued and armed gules. Supporters: dexter, a lion regardant or, langued and armed gules; sinister, a double-queued lion rampant sable, the head, manes, claws and tip of the tail or, langued and armed gules, with a cor- 


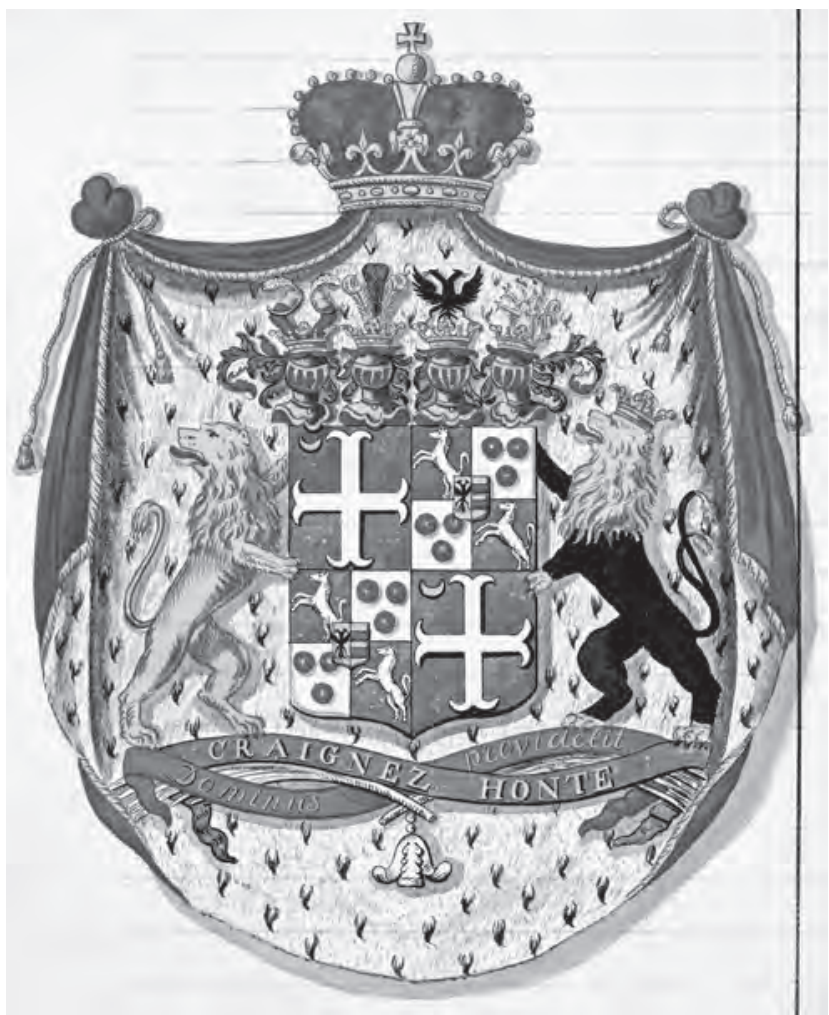

The Bentinck coat of arms (1814) registered in the armorials of the High Council of the Nobility (Archives of the High Council of the Nobility, The Hague, no. 501, B, fol. 63)

onet of three fleurons and two pearls. Mottos, on two crossing scrolls: first, CRAIGNEZ HONTE (fear the shame) in letters argent inscribed on a scroll azure; second, DOMINUS PROVIDEBIT (the Lord will provide) in letters or inscribed on a scroll gules. The whole coat of arms is placed on a mantle gules, with ermine lining and fringes and tassels or, surmounted by a coronet of a prince of the Holy Roman Empire (Fürstenkrone), lined gules. ${ }^{10}$

Exactly that same coat of arms (although the ostrich feathers are erroneously replaced by sickle-shaped cock's feathers sable) is depicted on the Ahnentafel (ancestral tree) presented to the Teutonic Order, Bailiwick of Utrecht, by Willem Gustaaf Frederik Bentinck as a Knight-expectant in $1822 .{ }^{11}$ The first and fourth (grand) quar- 
ters display the arms of Bentinck, with the addition of a crescent as a 'mark of cadency' (see below); the first crest and the first motto correspond with these quarters. In the second and third (grand) quarters, the armorial bearings of the counts of Aldenburg are depicted, to which the second, third and fourth crests, as well as the second motto, refer.

The Aldenburg coat of arms were granted to Anton I von Aldenburg (1633-1680), an illegitimate son of Anton Günther, Landesherr (sovereign lord) and Reichsgraf of Oldenburg and Delmenhorst and his fiancée, Elisabeth Margarethe Freiin von Ungnad-Sonnegg, Gräfin von Weissenwolff. He was created a Reichsfreiherr (Baron of the Holy Roman Empire) in 1651 and a Reichsgraf in 1653. The inescutcheon depicts in the sinister half the original Stammwappen of the house of Oldenburg, combined in the dexter half with the eagle of the Holy Roman Empire. This element was the so-called Gnadenwappen or Gnadenzeichen (corresponding with the third crest), an honorary armorial addition granted by the emperor. The horse in the first and fourth quarter are meant to be reminiscent to Widukind, the illustrious eighth-century king of the Saxons with his white horse (Sachsenross), of whom the house of Oldenburg claimed to descend. The roses in the second and third quarter of the Aldenburg coat of arms harked back to the medieval armorial bearings of the 'Wildeshauser Linie' of the counts of Oldenburg. ${ }^{12}$

\section{The (Van) Aldenburg Bentinck name}

It has to be pointed out that the name Aldenburg Bentinck was not used in the Netherlands until the 1840s. In the Decree of 1814, Willem Gustaaf Frederik Bentinck (Wilhelm Gustav Friedrich Reichsgraf von Bentinck) was mentioned with the name 'Bentinck van Rhoon' and until at least 1832, he was known as 'Bentinck van Rhoon' - the heerlijkheid (lordship) of Rhoon (with Pendrecht), bought in 1683 by Hans Willem Bentinck, was sold in 1830. Even in 1878, the Bentinck family described in Siebmacher's Wappenbuch as 'Grafen von Bentinck de Rhoon'.13

The first time the name Aldenburg Bentinck can be found in print in the Netherlands was in 1841, when the marriage of Willem Frederik Christiaan Aldenburg Bentinck (1787-1855), formally styled 'graaf Bentinck' in the Netherlands since 1822, with Pauline Albertine Gräfin von Münnich (1817-1898) was announced. George William Pierrepont Bentinck (1803-1886) and Charles Bentinck (1810-1891), grandsons of Jean Albert Bentinck (1737-1775, younger son of Willem Bentinck and Charlotte Sophie van Aldenburg and progenitor of another English branch), apparently called die nachfolge in die Reichsgräflich Aldenburg-Bentickschen Fideicommis-Herrschaften und Güter, Kniphause, Varel, Garms u.s.w. (Berlin, 1840) 24.

13 A.M.F. Gritzner (with illustrations by A.M. Hildebrandt), ed., J. Siebmacher's grosses und allgemeines Wappenbuch in einer neuen, vollständig geordneten und reich vermehrten Auflage mit heraldischen und historisch-genealogischen Erläuterungen (82 vols; Nürnberg, 1856-1938), X, Tafel 1. 


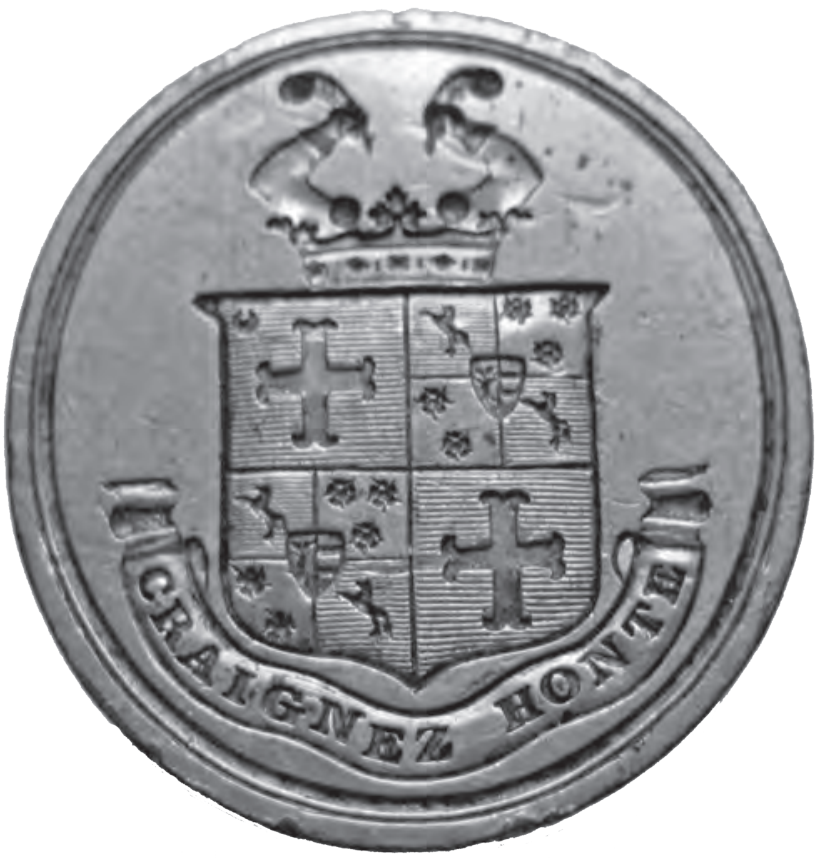

The Aldenburg Bentick arms on a nineteenth-

century signet with the crescent as a mark of cadency in the first grand quarter (mirrored image; coll. House Middachten, De Steeg/Rheden)

themselves 'Aldenburg-Bentinck'. ${ }^{14}$ Godard John George Charles (Godard Johann Georg Carl) Graf von Bentinck (1857-1940) was incorporated into the Dutch nobility in 1920 as 'graaf van Aldenburg Bentinck', his nephew William Frederick Charles Henry (Wilhelm Friedrich Carl Heinrich) Graf von Bentinck (1880-1958) in 1924 as 'graaf Aldenburg Bentinck' - without the prefix 'van'.

Since 1889, a branch of the (Van) Aldenburg Bentinck family was known in Germany as 'Von Bentinck und Waldeck-Limpurg', an alternative version of the name, simultaneously used until the death of the last member of this branch, Isabelle Adrienne Gräfin zu Ortenburg née gravin Aldenburg Bentinck, Gräfin von Bentinck und Waldeck-Limpurg (1925-2013).

\section{The appearing and vanishing crescent}

In the Bentinck coat of arms registered in 1814, a crescent (or) suddenly appears in the dexter chief point of the first and fourth quarter. The same sign already figured a few years earlier in the arms depicted on the coins of Varel and Kniphausen and on the flag of Kniphausen. This crescent is a so-called mark of cadency. In heraldry, 
otherwise identical arms belonging to members of the same family are often distinguished by cadency. The full, plain arms could only be borne by the eldest male, while younger male scions differentiated these arms by adding small, inconspicuous marks of cadency (cadet meaning younger in French) or 'brisures' (from the French briser, to break, as the mark 'breaks' the plain arms). This stringent system is almost exclusively practiced in British heraldry, but when considering the English background of the Bentinck family, the presence of a mark of cadency in the Bentinck arms is certainly not completely startling.

In British heraldry, a crescent is the brisure for the second son; Willem Bentinck (1704-1774), the grandfather of Willem Gustaaf Frederik Bentinck, was indeed the second son of the first Earl of Portland. However, one might assume that this version of his arms, broken by the crescent, was primarily used in England and not on the Continent, where this typical British heraldic cadency system was not usance. On the funerary hatchment of Willem Bentinck in the church of Rhoon, for instance, the Bentinck arms are displayed without a crescent. The hatchment of his son Antoine Bentinck (1734-1768), father of Willem Gustaaf Frederik shows the quartering of Bentinck and Aldenburg, again without the crescent. An engraving in silver of the coats of arms of Antoine and his spouse Maria Catharina van Tuyll van Serooskerken (1743-1793) depict the plain Bentinck arms, not quartered with Aldenburg, again without the crescent..$^{15}$

The mark of cadency was not used by his brother Jean Charles (1763-1833) though, as was the case with the (English) branch descending from Jean Albert Bentinck (1737-1775), lord Terrington. One might expect that all members of this younger lineage of the Portland branch would have born this crescent as mark of cadency. Yet this was not the case. Another peculiarity is that a nineteenth-century signet in the collection of the house of Middachten shows the Aldenburg Bentinck arms as registered in 1814, but now with only a crescent in the first (grand) quarter, not in the fourth. In an Ahnentafel of Willem Gustav Frederick Bentinck, drawn and approved by the Hoge Raad van Adel (the Dutch High Council of the Nobility) in 1822, the arms of his father Antoine (quartered with Aldenburg) and of his grandfather Willem Bentinck both bear the crescents as mark of cadency again. ${ }^{16}$

In the course of the nineteenth century, this crescent appears to have vanished. Moreover, in the first half of this century, most younger members of the Aldenburg

15 It is not unusual, certainly in case of rather complicated, fully marshalled coats of arms, to use a simple alternative, usually the plain coat of arms, without (some of the) augmentations. Especially in case of smaller objects (like a signet or a livery button), a 'simpler' depiction of the coat of arms is more practical. Hoogen Raad van Adel en later door den Minister van Binnenlandsche Zaken en dien van Justitie. Ingevolge Art. 22 der Instructie van den Hoogen Raad van Adel vastgesteld by Soeverein Besluit van 24 Juny 1814 No. 10 , fol. 16-17 (dated 8 Aug. 1822). With special thanks to Barend van Benthem and Jos van den Borne (Hoge Raad van Adel). 
Bentinck branch still used the full, plain Bentinck coat of arms, not marshalled with the arms of Aldenburg. This can be seen on the Ahnentafel presented to the Teutonic Order, Bailiwick of Utrecht, by Willem Frederik Christiaan Bentinck (1787-1855) as a Knight-expectant in 1838 and that of Carel Anton Ferdinand Bentinck (1792-1864), presented in $1841 .{ }^{17}$

The Bentinck arms in the already mentioned Siebmacher's Wappenbuch, published in 1878, still depicts the crescents in the Bentinck quarter. An explanation for this might possibly be that the illustration was based on the Sovereign Decree of 1814 . However, there are more noticeable aspects - deviations - in the depicted version: of the sinister supporter (the double-queued lion rampant sable), only the manes are or.$^{18}$ The scrolls with mottos - both in letters sable on a scroll argent - don not cross each other and the Bentinck motto is placed above the crests. Last but not least, the mantle is not surmounted by a princely coronet (Fürstenkrone) or hat (Fürstenhut) - both were interchangeable - but by a so-called Erlauchtkrone, basically a princely type of coronet but without the arches, as depicted on the coins of Varel and Kniphausen.

The generation of the Aldenburg Bentinck branch which entered the Teutonic Order between 1876 and 1894 used the Vollwappen (greater coat of arms) as described in the Decree of 1814, without the crescents, as Antoine Bentinck already bore in the mid-eighteenth century. One might question why Willem Gustaaf Frederik Bentinck, sovereign lord of Varel and Kniphausen, apparently decided to use (or revive) the mark of cadency in his coat of arms. After all, his father Antoine, grandfather Willem and brother Jean Charles apparently preferred the version without the crescent. Was it to emphasize his descent of the first Earl of Portland and his position in the line of succession to this title in the Peerage of England?

\section{The Von Bentinck und Waldeck-Limpurg coat of arms (1889)}

In 1846 Carl Anton Ferdinand Graf von Bentinck (1792-1864), son of Jean Charles, married Caroline Mechtild Emma Charlotte Christine Louise Gräfin von Waldeck und Pyrmont (1826-1899), an alliance that would be of great dynastic importance for the Aldenburg Bentinck family and which had heraldic consequences as well. Caroline was a descendant of Josias Graf von Waldeck-Bergheim (1696-1763) and Dorothea Sophie Wilhelmine zu Solms-Rödelheim und Assenheim (1698-1774), the latter a daughter of Wilhelmina Christina Schenk von Limpurg (1679-1757). She was also one of the heirs of Vollrath, the last male member of the Schenk von Limpurg family, who died without offspring in 1713. After many years of quarrelling between the various heirs (many of them claiming to be entitled to the Schenk von Limpurg heritage), the Standesherrschaft of Limpurg-Gaildorf-Solms-Assenheim, known as Waldeck-Limpurg, came into the hands of a branch of the house of Waldeck. In a fam- 
ily treaty dated 16 March 1868, Richard Kasimir Alexander Graf von Waldeck und Pyrmont (1835-1905) bequeathed Waldeck-Limpurg (together with, amongst others, Gaildorf) to his sister Mechtild, Gräfin von Bentinck.

Mechtild's eldest son, Heinrich Carl Adolph Friedrich Wilhelm Graf von Bentinck (Henry Charles Adolphus Frederick William Bentinck) ${ }^{19}$ (1846-1903), settled in England. In 1874, Henry Bentinck married Henrietta Eliza Cathcart McKerall (18481934). ${ }^{20}$ Miss McKerall was not ebenbürtig (of the same or a comparable noble rank), which was not only a faux pas but also incompatible with the rigid 'house laws' (Familiengesetz) of the house of Aldenburg Bentinck. This Mißheiraten or misalliance had for consequence that Henry Bentinck was no longer eligible to succeed in the Standesherrschaft. In 1888, Mechtild Gräfin von Bentinck therefore donated the Standesherrschaft to her second son, Wilhelm Carl Philipp Otto (William Charles Philip Otho) Graf von Bentinck (1848-1912), who was known in England as Count Aldenburg Bentinck. By Decree of Georg Victor Fürst von Waldeck dated 18 September 1889, Wilhelm Carl Philipp Otto, was granted the right to bear the name and arms of Waldeck. This branch of the Bentinck family would henceforth be known as Von Bentinck und Waldeck-Limpurg.

The Aldenburg Bentinck coat of arms was augmented consequently: in the third grand quarter, the arms of Aldenburg (already displayed in the second grand quarter as well) were replaced by the coat of arms of Waldeck-Limpurg, which can be described as follows: quarterly: first and fourth, azure, five battle clubs argent, placed three-two; second and third, per fess indented, gules and argent; overall, an inescutcheon: or, a mullet of eight points sable. Sinister, surmounting the shield, a fifth and a sixth helmet (with crest) were added to the four of Aldenburg Bentinck. The fifth crest: a vol (two wings) or, the wings charged with a mullet of eight points sable; the sixth crest: two so-called Büffelhörner or buffalo horns per fess indented, gules and argent, with a banner (Rennfähnlein) per fess gules and argent, issuant from the horns.

The quarters with the five clubs - Kolben in German, blunt instruments used in battle - are the original Schenk von Limpurg coat of arms. In the twelfth century, members of this family were also known as 'Colbo' and it might be assumed that one

19 When entering the Dutch branch of the Teutonic Order in 1894 (ADO, no. NA.131.0.122), Henry Bentinck was called 'graaf van Aldenburg Bentinck'. His branch, to which Timothy Charles Robert Noel Bentinck (b. 1953), twelfth Earl of Portland belongs, was never styled 'count Bentinck und Waldeck-Limpurg', as Wikipedia (regarding Henry Bentinck, eleventh Earl of Portland, still on 1 June 2018) states incorrectly: the title, name and arms of Waldeck(-Limpurg) were granted in 1889 to Wilhelm (William) Bentinck, younger brother of Heinrich (Henry).

20 His marriage with the beautiful and, to quote their grandson Henry Noel Bentinck, eleventh Earl of Portland (1919-1997), 'by all accounts totally brainless' miss McKerall, seemed to have been very passionate, but was heavily frowned upon and disapproved by the family. 'The Bentincks were socking great Dutch snobs. (...) The Bentincks were ruling Counts. We once had our own army - twelve men and our own currency and ruled the principality of Aldenburg. On the whole (...) the Bentincks couldn't and didn't communicate in any way with the world, learned nothing from it, and drew back from it fastidiously (...)' - Henry Bentinck, Clogs to clogs in six hundred years (s.d.), 5-6. 


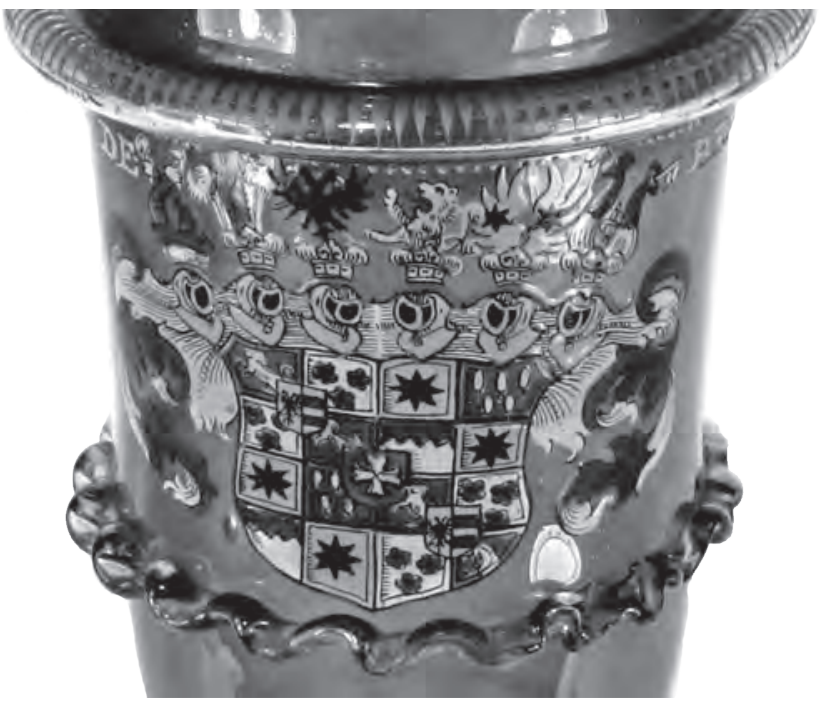

The Bentinck coat of arms painted in enamel on a goblet in Historismus style (coll. Heimatmuseum Varel)

(or some) of these medieval Schenken had a certain preference for the use of this type of weapon. Since the late fourteenth century, the Schenk von Limpurg family quartered their coat of arms with these of Franken (der Fränkische Rechen), depicted in the second and third quarter.

It should be noticed that sometimes, a so-called Doppelkanne (double jug) (or) was placed between the buffalo horns of the Schenk von Limpurg crest. This jug was the original crest of the Schenk von Limpurg family, referring to the name and the honourable position of Reichserbschenker, hereditary superintendent of the imperial wine cellars, an office held by this family since the twelfth century. On the Ahnentafel presented to the Teutonic Order by Willam Frederick Charles Henry Bentinck (1880-1958) in $1903,{ }^{21}$ the jug is absent in the Schenk von Limpurg crest, but it can distinctly be seen on an engraving in silver.

A remarkable version of the Bentinck coat of arms after the augmentation with these of Waldeck-Limpurg in 1889 is painted in enamel on a goblet in Historismus style. Here, the Bentinck arms are quartered with those of Aldenburg (first and fourth grand quarter) and Waldeck-Limpurg (second and third grand quarter), with the Stammwappen Bentinck over all in an escutcheon. The quartered Waldeck-Limpurg coat of arms deviate from the version described above: now, the Waldeck arms are depicted in the first and fourth quarter, the second and third quarter show the Stammwappen of Schenk von Limpurg respectively the coat of arms of Franken. Again, the ancient Doppelkanne crest is placed between the Fränkische Büffelhörner 

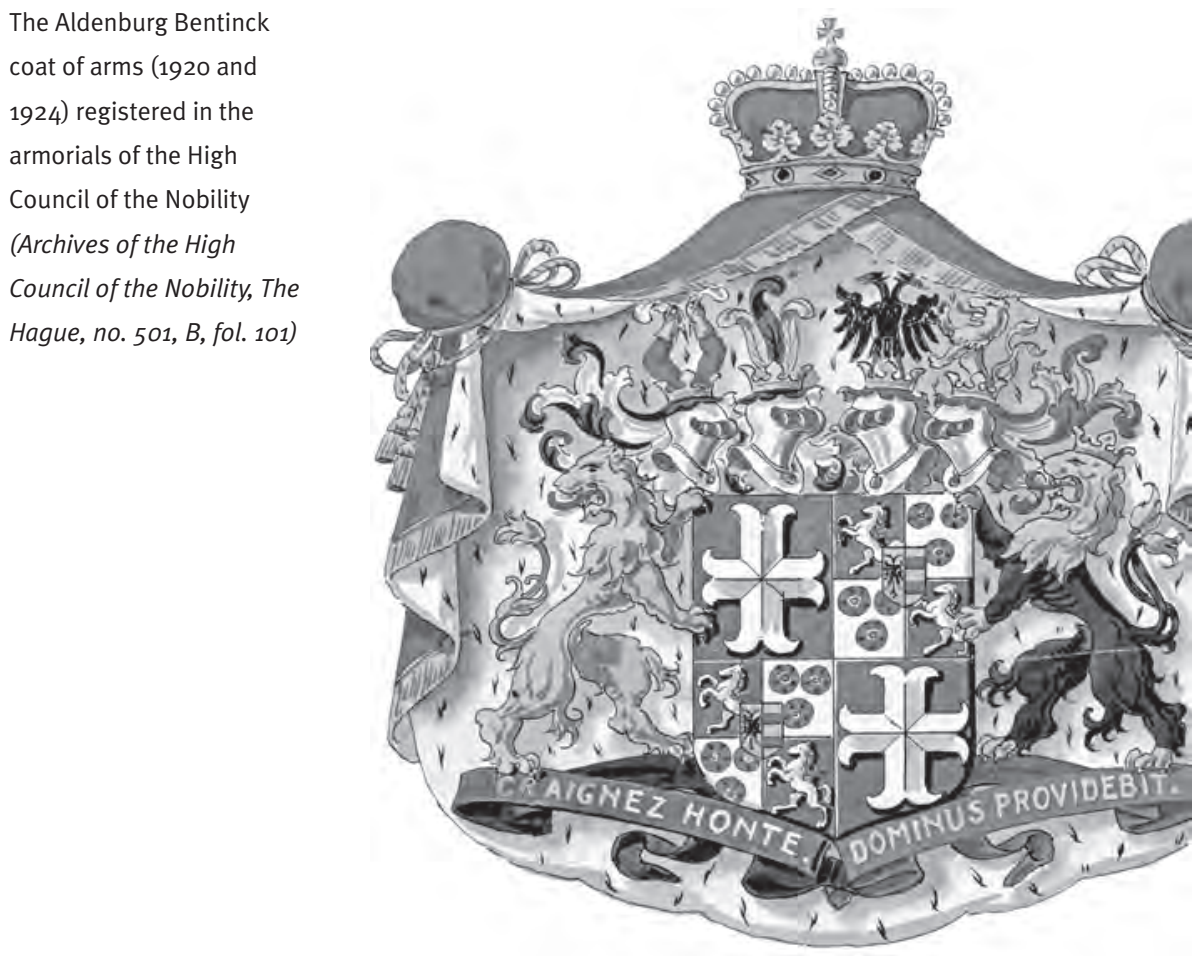

in the Schenk von Limpurg crest. Probably, this rendition of the Von Bentinck und Waldeck-Limpurg coat of arms has arisen from the fantasy and interpretation of the craftsman who painted this goblet. Another comparable version is unknown.

The augmentation of the Bentinck arms with those of Waldeck-Limpurg only regard Wilhelm Bentinck (1848-1912), to whom this right was granted in 1889. Therefore, the Ahnentafel of his nephew John Victor Richard Rodolphe van Aldenburg Bentinck (1895-1963), son of Godard John George Charles van Aldenburg Bentinck (1857-1940, since 1920 a Dutch count), drafted in 1916 in order to be admitted to the Teutonic Order, shows the Aldenburg Bentinck coat of arms without the quarter and the crests of Waldeck-Limpurg.

\section{The (Van) Aldenburg Bentinck coat of arms (1920 and 1924)}

By Royal Decree of Queen Wilhelmina of the Netherlands dated 24 June 1920 (no. 66), Godard John George Charles (Godard Johann Georg Carl) Graf von Aldenburg Bentinck (1857-1940) was enrolled in the Dutch nobility as 'graaf van Aldenburg Bentinck'. A few years later, by Royal Decrees of 22 May 1924 (nos 28 and 29), his nephews William Frederick Charles Henry (Wilhelm Friedrich Carl Heinrich) Aldenburg Graf von Bentinck (1880-1958) and Frederik Geoge Unico Willem (Frie- 
drich Georg Unico Wilhelm) Graf von Bentinck (1888-1942) were incorporated in the Dutch nobility as 'graaf Aldenburg Bentinck' respectively 'graaf Bentinck'.22

The coat of arms, confirmed in these Decrees, are practically identical to the coat of arms in the Decree of 1814: the arms of Bentinck quartered with those of Aldenburg, but without the crescent in the Bentinck coat of arms. The mottos ('Craignez Honte' and 'Dominus Providebit') were not placed on two intertwined scrolls as in 1814 , but on scrolls depicted next to each other.

\section{The cross-border appearance of the (Aldenburg) Bentinck arms}

The basic rules of heraldry are, in general, comparable all over Europe. However, various countries and regions developed their own ways of displaying arms. For a heraldist, coats of arms can often be recognised immediately as, for example, typically English, German, Italian, Swiss, Polish or French, often because of the use of (a combination of) specific ordinaries, subordinaries and figures. ${ }^{23}$ However, the appearance - the manner of display - of coats of arms can be regarded as typical for a certain country as well.

Some of the manifestations of the Bentinck coat of arms can be regarded as typical German or English. After all, and as emphasised, the Bentincks were a cross-border aristocratic family, with branches belonging to the nobility of the Netherlands, Germany and England. This multinational character has been displayed in various ways and is in particular apparent in the way members of the Aldenburg Bentinck branch displayed their coats of arms.

As explained, the shield in the Aldenburg Bentinck coat of arms is surmounted by four helmets, each of course with its individual crest. Since 1889 , when the arms of Waldeck-Limpurg was added to the escutcheon (replacing the Aldenburg arms in the third quarter of the shield), no less than six helmets and crests surmounted the shield. The use of more than three helmets (and crests) is a rather typical German phenomenon. In the heraldry of the United Kingdom, on the contrary, an escutcheon surmounted by two helmets is quite an exception. In the heraldry of the Netherlands, sporadically, three or more helmets surmount the shield. Only three Dutch families (apart from Aldenburg Bentinck) with four helmets or more can be found. In Germany however, up to fifteen helmets might surmount a shield. The coat of arms of Aldenburg Bentinck, with four or even six helmets, is therefore a fine example of a German armorial tradition.

$$
\text { in Fren }
$$

\section{in} so-called 'capo dell'Impero', are practically always Italian, while those depicting a severed head of a moustached Turc are almost without exception the armorial bearings of Hungarians and Transylvanians.

melpenninck van der Oije et al., Wapenregister van de Nederlandse adel, 67-68. 

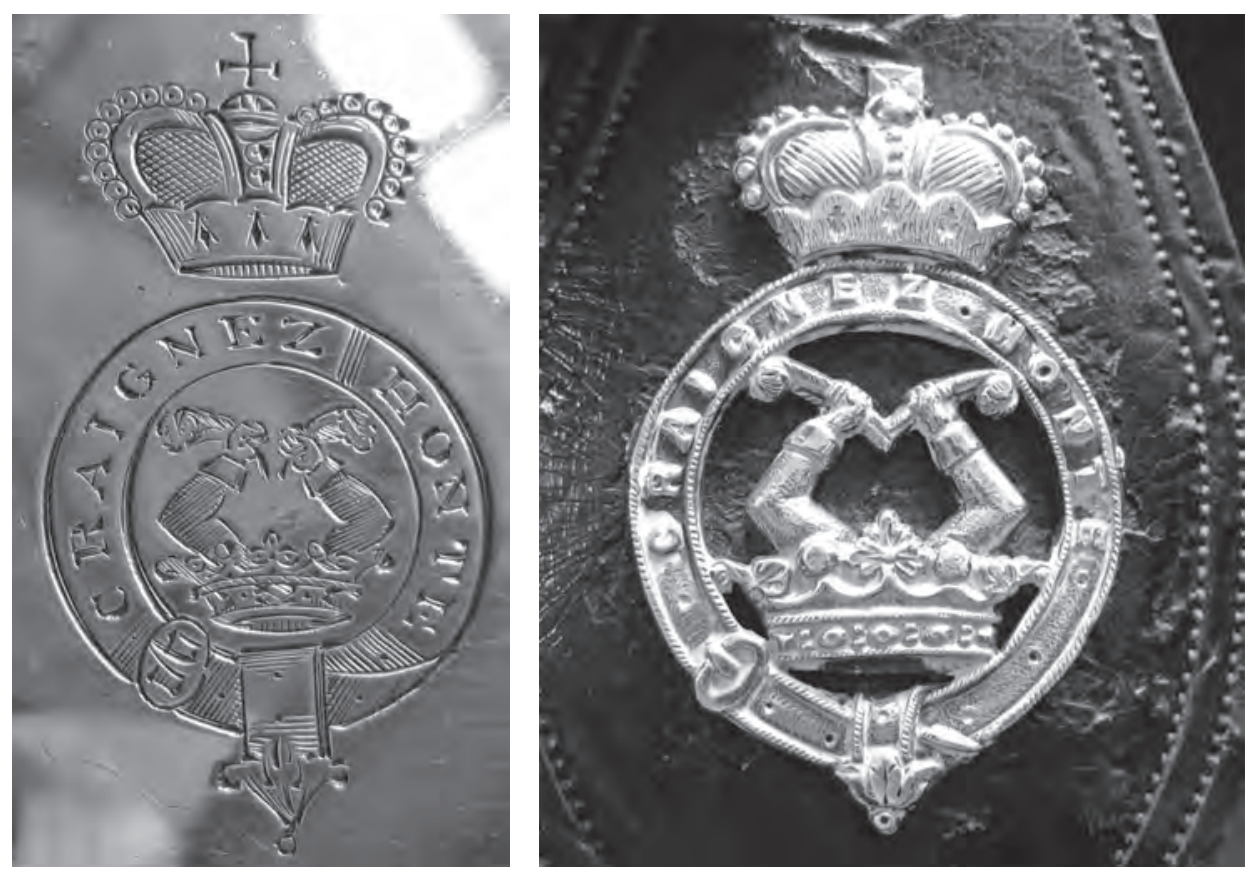

Silverware and horse gear from the Aldenburg Bentinck household (coll. House Middachten, De Steeg) Rheden)

On the other hand, despite the German appearance of this greater coat of arms, the heraldic display of the Aldenburg Bentinck family clearly demonstrates an indisputable orientation on England and gives evidence of the Anglophile character of the family. This is not surprisingly, as this branch of the Bentinck family - after all descending from Hans Willem Bentinck (1649-1709), created first Earl of Portland, Viscount Woodstock and Baron Cirencester in 1689 by King-Stadtholder William III had close ties with England. Various members served as officers in the British army. In 1886, all descendants in male lineage of Jean Charles (John) Bentinck (1763-1833), married to Jacoba Helena (Jemima) van Reede-Ginkel (1767-1839), daughter of the fifth Earl of Athlone, obtained Royal Licence from Queen Victoria 'to assume and use their foreign honours' in the United Kingdom and were henceforth formally 'Count Aldenburg Bentinck' in Great Britain. Wilhelm Carl Philip Otto Graf von Bentinck und Waldeck-Limpurg (1848-1912) was known as William Charles Philip Otho Count Aldenburg Bentinck. ${ }^{24}$ 


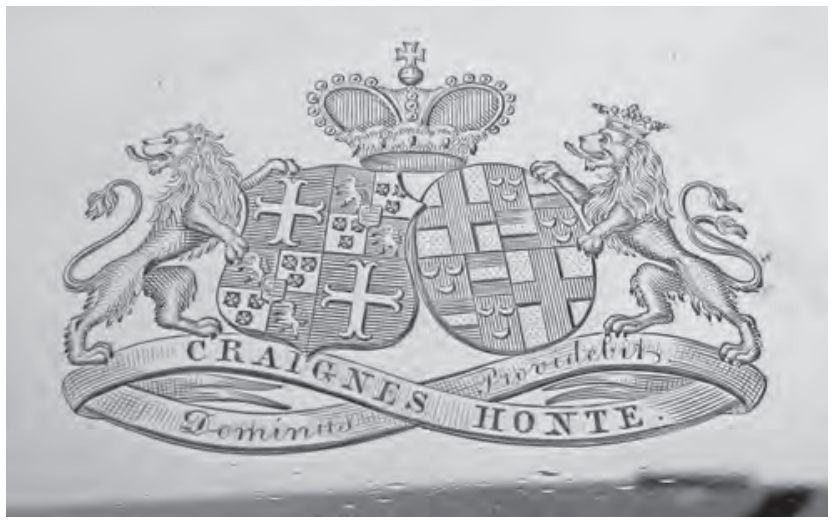

Silverware with an engraving of the coats of arms of Willem Carel Philip Otto, Count of Aldenburg Bentinck and Waldeck-Limpurg (1848-1912) and Maria Cornelia, Baroness Van Heeckeren van Wassenaer (18551912), married in 1877. The arms are surmounted by a Fürstenkrone; that is, the coronet of a prince of the Holy Roman Empire (coll. House Middachten, De Steeg/Rheden)

A typical heraldic phenomenon in the United Kingdom is the almost supreme importance of the crest. Contrary to continental Europe, where the shield is the crucial and indispensable essence of a coat of arms, superior to all the other parts, the British seem to have a preference for displaying only the crest itself, without the helmet, placed on/or emerging from a wreath or, as is the case with the Bentinck achievement, a coronet, sometimes combined with a princely coronet (Fürstenkrone or Fürstenhut). Through armorial display on various objects, the Aldenburg Bentinck family manifested its English identity with emphasis. For instance, the Bentinck crest is engraved in silverware, for example on an entry dish (circa 1885-1890) and on livery buttons, where the Bentinck crest is surmounted by the Fürstenhut.

Another outspoken British heraldic custom - apart from the isolated use of the crest - can be seen on silverware and horse gear from the Aldenburg Bentinck household: the crest is encircled by a garter with the motto 'Craignez Honte'. The use of a garter - encircling an escutcheon or crest - instead of a scroll to display the motto is even more exclusively British, although some heraldists considered it incorrect, or at least pretentious. After all, it might (wrongly) suggest that the bearer of the gartered arms is a Knight of the Most Noble Order of the Garter. 'The practice of encircling the arms with a garter is incorrect, for we never read of the motto on a garter; on the contrary, it is uniformly inscribed on a scroll or pennon. Inscribing it on a garter has too much the imitation of knights of the garter', as Alexander Deuchar, seal engraver to the Prince Regent (the later king George IV), wrote in $1817 . .^{25}$ Despite his objection to

titles of nobility in the United Kingdom should be discontinued in due course. In 1932, he revoked all Royal Decrees which had allowed the use of the foreign dignitaries and titles, amongst others that of 22 April 1886 obtained by the heirs of Jean Charles Bentinck. The holders, their sons and grandsons could nevertheless continue to use their title during their own lifetime. Apart from these exceptions, no official recognition of foreign nobility is given anymore.

25 A. Deuchar, The crests and mottos of the families of Great Britain and Ireland; together with those of the principal cities and a glossary of heraldic terms (Edinburgh-London, 1817) 31-32. A 'pennon' or 
this practice, the use of a garter in British heraldry is all but exceptional.

Exemplary for the sometimes almost hybrid 'Anglo-German' heraldic tradition in the Aldenburg Bentinck family is a nineteenth-century seal. ${ }^{26}$ The seal shows us all four crests of Aldenburg Bentinck, the Bentinck crest and the three crests of Aldenburg: the three ostrich feathers, the demi-lion rampant issuant and the double eagle issuant (the Gnadenzeichen). The whole appearance of this seal - the display of nothing but crests - is British, the use of four crests is typically German.

\section{Conclusion}

It is very intriguing to see how a branch of a landed aristocratic Dutch family managed to be admitted to the Peerage of England in 1689, raised into the high nobility of the Holy Roman Empire in 1732, obtained sovereignty over the miniature state of Varel and Kniphausen and belonged to the German Hohe Adel from 1845 till 1919. The family owned vast properties and splendid houses - Middachten, Amerongen, Weldam - and held 'court' in The Hague. This transnational rise of the family manifested itself clearly and distinctly in a visual form, which is most apparent in their heraldic display. By marshalling the arms of Bentinck with those of Aldenburg and, from 1889 onwards, with the arms of Waldeck-Limpurg, the individual members explicitly accentuated and exhibited their dynastic lineage and territorial acquisitions. The display of a Fürstenkrone or Fürstenhut affirmed the sovereign and princely status of this branch of the Bentinck family, whether depicted on silverware, on seals, carriages or livery buttons. In the way the Aldenburg Bentincks marshalled and displayed their armorial bearings, the cross-border character of this family - Dutch, German and English - became evident. The heraldic imagery adhered to British heraldic customs but fused these with typically German elements.

\footnotetext{
Olivier Mertens studied Civil Law at Leiden University and received his LLM degree in 2004. Between 2005 and 2016, he worked at Sotheby's in Amsterdam and as legal counsel in The Hague. From his early youth, Mertens has been fascinated by heraldry and genealogy. In 2016, he founded the consultancy company Artmorial, specialised in researching coats of arms (and monograms), identifying portraits and unravelling genealogical mysteries, advising art dealers, auction houses, museums and private collectors worldwide. Since 2018, Mertens is a member of the board of the Royal Dutch Society for Genealogy and Heraldry (KNGGW).
}

Witte de Withstraat 42A, 2518 CV, The Hague, the Netherlands - oliviermertens@hotmail.com 
Adellijke echo's? De invloed van de adel op de ontwikkeling van buitenplaatsen langs de rivieren van het Amstelland en de Oude Rijn

Gerrit van Oosterom

Het Staatse ambassadegebouw in de zeventiende eeuw. Het logement van Hendrick van Reede van Renswoude in Madrid, 1656-1669

Maurits Ebben

Naar het Oosten. Geografische verschillen in het ledenbestand van de Ridderlijke Duitsche Orde, Balije van Utrecht, 1640-1840

Renger E. de Bruin

De Belgische orangistische adel I. De zuidelijke adel in het Verenigd Koninkrijk 79 der Nederlanden (1815-1830)

Els Witte

The Bentinck family archives. Highlights and suggestions for further research Menoucha Ruitenberg

Bildung und Erziehung. Zur Bedeutung zweier Schlüsselkategorien für Charlotte Sophie Gräfin Bentinck

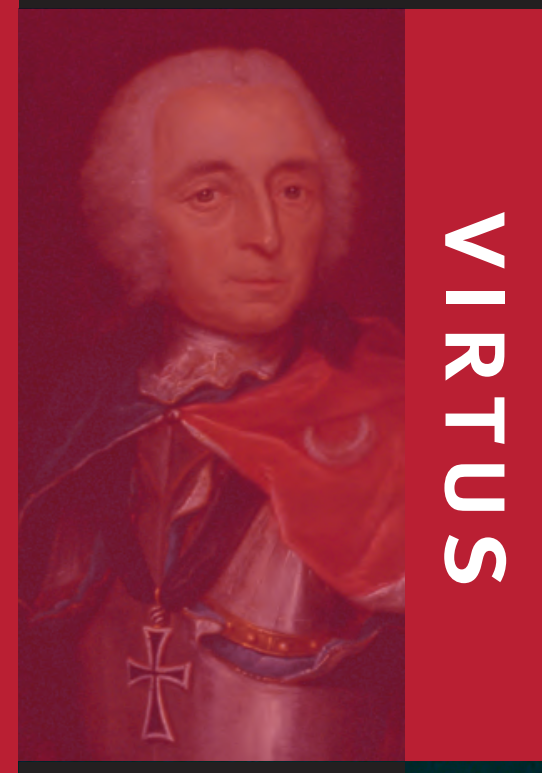

25 | 2018

Christina Randig

Charlotte Sophie, Joseph Eckhel and numismatics

Daniela Williams

Craignez honte. The Bentinck coats of arms and their use as an expression of the cross-border character of the family

\section{Olivier Mertens}

Fathers and Sons. A sketch of the noble life forms of the Bentincks in the 162 period of the Great Wars in Europe (1672-1748)

Yme Kuiper

Van wapenbord tot koningsboek. Herinnering, herstel en herbestemming in de heraldiek van het Gulden Vlies (1559-1795)

Steven Thiry 